\title{
Handbook of Florida Water Regulation: Table of Contents ${ }^{1}$
}

Michael T. Olexa, Luke D'Isernia, Laura Minton, Dulcy Miller, and Sarah Corbett ${ }^{2}$

\section{Preface}

This handbook is designed to provide an accurate, current, and authoritative summary of the principle Federal and Florida laws that directly or indirectly relate to agriculture. This handbook should provide a basic overview of the many rights and responsibilities that farmers and farmland owners have under both Federal and Florida laws as well as the appropriate contact information to obtain more detailed information. However, the reader should be aware that because the laws, administrative rulings, and court decisions on which this handbook is based are subject to constant revision, portions of this publication could become outdated at anytime.

Several details of cited laws are also left out due to space limitations.

This handbook is distributed with the understanding that the authors are not engaged in rendering legal or other professional advice, and the information contained herein should not be regarded as a substitute for professional advice. This handbook is not all inclusive in providing information to achieve compliance with the Federal and Florida laws and regulations governing water protection. For these reasons, the use of these materials by any person constitutes an agreement to hold harmless the authors, the Florida Cooperative Extension Service, the Institute of Food and Agricultural Sciences, and the University of Florida for any liability claims, damages, or expenses that may be incurred by any person as a result of reference to or reliance on the information contained in this handbook.

\section{Table of Contents}

- Introduction (FE580)

- State Regulatory Powers (FE581)

- Federal Laws and Florida State Laws

- Clean Water Act (FE582)

- Resource Conservation and Recovery Act (FE583)

1. This is EDIS document FE579, a publication of the Food and Resource Economics Department, Florida Cooperative Extension Service, Institute of Food and Agricultural Sciences, University of Florida, Gainesville, FL. Published December 2005. Please visit the EDIS website at http://edis.ifas.ufl.edu.

2. Michael T. Olexa, Professor, Food and Resource Economics Department, Florida Cooperative Extension Service, Institute of Food and Agricultural Sciences, University of Florida, Gainesville, FL; Director, Agricultural Law Center, University of Florida, Gainesville, FL; and Chair, Agricultural Law Committee of The Florida Bar. Luke D'Isernia, former student (graduated cum laude in 2005), Levin College of Law, University of Florida, Gainesville, FL. Laura Minton, Attorney, Dean, Mead, Egerton, Bloodworth, Capouano, and Bozarth, Orlando, FL. Dulcy Miller, attorney, Foley and Lardner, LLP, Orlando, FL. Sarah Corbett, Attorney, Florida Second District Court of Appeal, Lakeland, FL.

The Institute of Food and Agricultural Sciences (IFAS) is an Equal Opportunity Institution authorized to provide research, educational information and other services only to individuals and institutions that function with non-discrimination with respect to race, creed, color, religion, age, disability, sex, sexual orientation, marital status, national origin, political opinions or affiliations. U.S. Department of Agriculture, Cooperative Extension Service, University of Florida, IFAS, Florida A. \& M. University Cooperative Extension Program, and Boards of County Commissioners Cooperating. Larry Arrington, Dean 
- Comprehensive Environmental Response, Compensation, and Liability Act (FE584)

- Florida Pollutant Discharge Prevention and Control Act (FE585)

- Emergency Planning and Community Right-to-Know Act (FE586)

- Safe Drinking Water Act (FE587)

- Federal Insecticide, Fungicide, and Rodenticide Act (FE588)

- Food Quality Protection Act (FE589)

- Florida Pesticide Law (FE590)

- Toxic Substances Control Act (FE591)

- Endangered Species Act (FE592)

- State Agencies

- Florida Department of Environmental Protection (FE593)

-Water Management Districts (FE594)

- Fish and Wildlife Conservation Commission (FE595)

- Florida Department of Agriculture and Consumer Services (FE596)

- Florida Department of Health (FE597)

- Private Regulation (FE598)

- Florida Right-to-Farm Act (FE599)

- Environmentally Safe Practices (FE600)

- Groundwater Discharge Regulations at the State Level (FE601)

- Groundwater Discharge Regulations at the Federal Level (FE602)

- Water Wells (FE603)

- Consumptive Use (FE604)

- Management and Storage of Surface Waters (FE605)
- Activities in Wetlands and Watersheds (FE606)

- Florida Air and Water Pollution Control Act (FE607)

- Florida Watershed Restoration Act (FE608)

- Florida Everglades Forever Act (FE609)

- Florida Lake Okeechobee Protection Act (FE610)

- Waste Management

- Solid Waste Management (FE611)

- Hazardous Waste Management (FE612)

- Pollutant Storage Tank Systems (FE613)

- On-Site Sewage Treatment and Disposal (FE614)

- Appendix (FE615)

- Contact Agencies (FE616)

- Notes and Glossary (FE617)

\section{Acknowledgments}

The authors are indebted to the personnel of both state and federal agencies who provided their time and advice in the preparation of this handbook. The authors are especially indebted to Richard Budell of the Office of Agricultural Water Policy of the Florida Department of Agriculture and Consumer Services for providing funds for the development of this publication. 